\title{
Modulation of benzo[a]pyrene-DNA adduct formation by CYP1 inducer and inhibitor
}

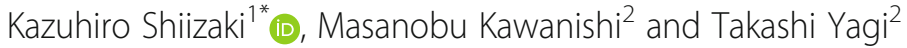

\begin{abstract}
Benzo[a]pyrene (BaP) is a well-studied pro-carcinogen that is metabolically activated by cytochrome P450 enzymes. Cytochrome P4501A1 (CYP1A1) has been considered to play a central role in the activation step, which is essential for the formation of DNA adducts. This enzyme is strongly induced by many different chemical agents, including 2,3,7,8-tetrachlorodibenzo- $p$-dioxin (TCDD), which binds to the aryl hydrocarbon receptor (AhR). Therefore, AhR activators are suspected to have the potential to aggravate the toxicity of BaP through the induction of CYP1A1. Besides, CYP1A1 inhibitors, including its substrates, are estimated to have preventive effects against BaP toxicity. However, strangely, increased hepatic BaP-DNA adduct levels have been reported in Cypla1 knockout mice. Moreover, numerous reports describe that concomitant treatment of AhR activators reduced BaP-DNA adduct formation. In an experiment using several human cell lines, TCDD had diverse modulatory effects on BaP-DNA adducts, both enhancing and inhibiting their formation. In this review, we focus on the factors that could influence the BaP-DNA adduct formation. To interpret these complicated outcomes, we propose a hypothesis that CYP1A1 is a key enzyme for both generation and reduction of ( \pm )-anti-benzo[a]pyrene-7,8-diol-9,10-epoxide (BPDE), the major carcinogenic intermediate of BaP. Conversely, CYP1B1 is thought to contribute only to the metabolic activation of $\mathrm{BaP}$ related to carcinogenesis.
\end{abstract}

Keywords: DNA adduct, Benzo[a]pyrene, Aryl hydrocarbon receptor, Cytochrome P450

\section{Background}

Benzo $[a]$ pyrene $(\mathrm{BaP})$ is a well-researched precarcinogen found in cigarette smoke, cooked food, and various combustion gases, such as vehicle exhausts [1-3]. BaP is biotransformed by several enzymatic steps to its ultimate carcinogenic forms, which are highly reactive electrophilic intermediates and form DNA adducts by covalent binding $[1,4-6]$ The ultimate carcinogenic intermediate of $\mathrm{BaP}$ is $( \pm$ )-anti-benzo[a]pyrene-7,8-diol-9,10-epoxide (BPDE). The metabolic enzymes required for BPDE production are thought to be cytochrome P4501A1 and 1B1(CYP1A1 and 1B1). These enzymes are highly inducible by polycyclic aromatic hydrocarbons (PAHs), such as 3-methylcholanthrene and $\mathrm{BaP}$ [7]. This induction is directed by a ligand-activated transcriptional factor named aryl hydrocarbon receptor (AhR) $[8,9]$, known as a dioxin receptor. Following the binding to ligands,

\footnotetext{
*Correspondence: shiizaki@toyo.jp

'Department of Applied Biosciences, Faculty of Life Sciences, Toyo University, Itakura, Gunma 374-0193, Japan

Full list of author information is available at the end of the article
}

AhR translocates to the nucleus and forms a heterodimer with AhR nuclear translocator (ARNT) [10]. The AhR/ARNT complex enhances the transcription of target genes including CYP1A1, 1A2, and 1B1 [11]. Therefore, BaP enhances its own metabolic enzyme expression by binding to $\mathrm{AhR}$ as a ligand and acquiring mutagenicity [12]. Structural diversity of exogenous and endogenous AhR ligands has been reported [13]. They are found not only in combustion products but also in food, such as dietary herbal supplements, vegetables, and fruits. These ligands would be ingested daily and could aggravate the toxicity of $\mathrm{BaP}$ through the induction of metabolic enzymes [14]. In contrast, $A h R$ antagonists, which can prevent CYP enzyme induction, have the possibility of reducing $\mathrm{BaP}$ adducts [15-17]. This indicates the possibility of modulating BaP toxicity by altering AhR activity. In fact, lack of BaP carcinogenicity in the skin of AhR knockout mice was observed [18]. In addition, AhR agonists would be expected to aggravate BaP toxicity through CYP enzyme induction, while AhR antagonists may prevent such toxicity. 
Contrary to this assumption, in vivo and in vitro experiments have shown that BaP-DNA adduct formation was suppressed by pretreatment with a potent AhR agonist, 2,3,7,8-tetrachlorodibenzo-p-dioxin (TCDD) [19-21]. Strangely, AhR knockout mice exhibited an enhanced $\mathrm{BaP}$ adduct level after the oral administration of $\mathrm{BaP}$ [22]. Other studies on the effects of AhR activator on BaP-DNA adduct formation also appeared to provide paradoxical results [23-29]. Table 1 shows a summary of previous studies about the alteration of $\mathrm{BaP}$ toxicity and adduct formation by natural compounds and artificial chemicals. Because these compounds include not only AhR agonist ligands but also non-ligand AhR activator and antagonist ligands, we refer to them as AhR modulators in this review. Many AhR modulators are substrates of CYP enzymes and some of them are known as CYP inhibitors [30]. This might be one of the reasons why these various and complicated results have been obtained.

After summarizing the enzymes involved in $\mathrm{BaP}$ metabolism, we provide a range of experimental results about the effects of $\mathrm{AhR}$ modulators on $\mathrm{BaP}$ adduct formation. Finally, this review focuses on the expression profile of CYP isoforms in cells in order to interpret these complicated, paradoxical, and enigmatic results.

\section{BaP catalytic enzymes and their induction by AhR}

Several mammalian enzymes involved in BaP metabolism have been reported [31-34]. CYP1A1, 1A2, 1B1, $2 \mathrm{C} 9,2 \mathrm{C} 19$, and $3 \mathrm{~A} 4$ are considered to be the oxidation enzymes of $\mathrm{BaP}$. Among these enzymes, $\mathrm{BaP}$ metabolites that can form DNA adducts were generated by CYP1A1, 1B1, and 2C19 [24]. The products generated by these CYP subtypes are considered to be benzo[a]pyrene 7,8-epoxide and BPDE. CYP1A1 is expressed ubiquitously and CYP2C19 is expressed specifically in the liver, while CYP1B1 is expressed in extrahepatic tissues $[35,36]$. AhR regulates the inducible expression of the CYP1A1 and 1B1 genes, but not that of CYP2C19 [37]. Therefore, the expression of these two enzymes would contribute to the modulation of $\mathrm{BaP}-\mathrm{DNA}$ adduct formation in the presence of additional AhR ligands other than BaP. Another enzyme involved in $\mathrm{BaP}$ metabolism is epoxide hydrolase (EPHX). Benzo[a]pyrene-7,8-epoxide, an CYP1A1 or CYP1B1 metabolite of BaP, is transformed to benzo[a]pyrene-7,8-dihydrodiol by microsomal epoxide hydrolase (EPHX1). Then, benzo[a]pyrene-7,8-dihydrodiol is catalyzed to BPDE by CYP1A1 or CYP1B1. EPHX1 and CYP are considered to generate BPDE in a coordinated manner [38]. EPHX1 gene regulation by the transcription factor GATA-4 has been reported, but EPHX1 is not an AhR target gene [24, 39]. For the conjugating enzymes, UDP-glucuronosyltransferase (UGT) subtypes UGT1A1 and UGT1A6 and glutathione transferase (GST) subtypes GSTA1, GSTA2, GSTA4, GSTM1, GSTP1, and microsomal GST play roles in generating hydrophilic conjugates. Among these enzymes, UGT1A1 induced by TCDD via AhR was reported. Overall, CYP1A1, CYP1B1, and UGT1A1 are most likely to influence BaP-DNA adduct formation via AhR activators.

Table 1 Influence of benzo[a]pyrene DNA adduct by various compounds

\begin{tabular}{|c|c|c|c|c|}
\hline Reference & Cells/organs & Compound & Physiological property & Modulation of $\mathrm{BaP}$ adduct \\
\hline de Waard et al. [20] & Caco-2 (human colorectal carcinoma) & TCDD & AhR agonist & reduction \\
\hline Gelhaus SL [21] & H358 (human lung carcinoma) & TCDD & AhR agonist & enhancement \\
\hline Wu Q et al. [19] & mouse liver & TCDD & AhR agonist & reduction \\
\hline Harrigan JA et al. [23] & rat lung and liver (ex vivo) & TCDD & AhR agonist & enhancement \\
\hline Shiizaki K et al. [24] & HepG2 (human hepatoma) & TCDD & AhR agonist & reduction \\
\hline Hodek P et al. [15] & rat liver/small intestine & BNF & AhR agonist & enhancement \\
\hline Chang KW et al. [25] & A427 and CL3 (human lung carcinoma) & $\begin{array}{l}\text { BNF } \\
\text { ANF }\end{array}$ & $\begin{array}{l}\text { AhR agonist } \\
\text { AhR antagonist/CYP1A1 inhibitor }\end{array}$ & enhancement reduction \\
\hline Mohebati A et al. [16] & MSK-Leuk & ANF carnosol & $\begin{array}{l}\text { AhR antagonist/CYP1A1 inhibitor } \\
\text { (AhR antagonist) }\end{array}$ & $\begin{array}{l}\text { reduction } \\
\text { reduction }\end{array}$ \\
\hline Takemura $\mathrm{H}$ et al. [26] & MCF-7 (human breast adenocarcinoma) & chrysoeriol & CYP1A1/1B1 inhibitor & reduction \\
\hline Wen X et al. [27] & SCC-9 (human squamous carcinoma) & 5,7-DMF & CYP1B1 inhibitor & reduction \\
\hline Kang ZC et al. [14] & HepG2 & quercetin & AhR activator & reduction \\
\hline Vanhees K et al. [54] & mouse liver (ex vivo) & quercetin & AhR activator & reduction \\
\hline Revel A et al. [17] & mouse lung & resveratrol & AhR antagonist & reduction \\
\hline Sehgal A et al. [28] & mouse liver and lung & curcumin & CYP1A1 inhibitor/(AhR agonist) & reduction \\
\hline Kleiner HE et al. [29] & MCF-7 (human breast adenocarcinoma) & coumarins & CYP1A1/1B1 inhibitor & reduction \\
\hline
\end{tabular}




\section{Suppression of BaP adduct formation by TCDD}

To investigate the modulation of BaP-induced DNA adduct formation by AhR agonists, TCDD is considered to be the most favorable ligand. This is because TCDD has been identified as the most potent ligand of AhR and shown not to be biotransformed and could not form any DNA adducts. An in vivo study showed that treatment with TCDD prior to $\mathrm{BaP}$ exposure suppressed the formation of BaP-induced DNA adducts in mouse liver. In human colon carcinoma cells $\mathrm{Caco} 2$ and human lung carcinoma cells H358, BaP-DNA adduct formation was found to be suppressed by TCDD treatment [20, 21]. In our study, concomitant exposure to AhR activators and $\mathrm{BaP}$ showed a wide variety of both protective and aggravative effects. Figure 1 shows the alteration of $\mathrm{BaP}$ adduct formation by various AhR ligands and activators in human hepatoma HepG2 cells (adapted from data reported previously [24]). Remarkably, TCDD significantly reduced $\mathrm{BaP}$-induced mutagenicity and the protective effects. These protective effects by TCDD were more significant upon BPDE exposure and were estimated to involve induction of a BPDE catalytic enzyme [24]. Among candidate enzymes for this, UGT1A1 was considered to be the most likely because it is natural that conjugating enzymes should reduce the activated form of $\mathrm{BaP}$; however, in this report, sulforaphane-induced UGT1A1 did not suppress any DNA adduct formation. Besides, CYP1A1 artificially induced due to the "tet-on gene regulation system" reduced $\mathrm{BaP}-\mathrm{DNA}$ adduct formation induced by BPDE [24]. Therefore, CYP1A1 is the

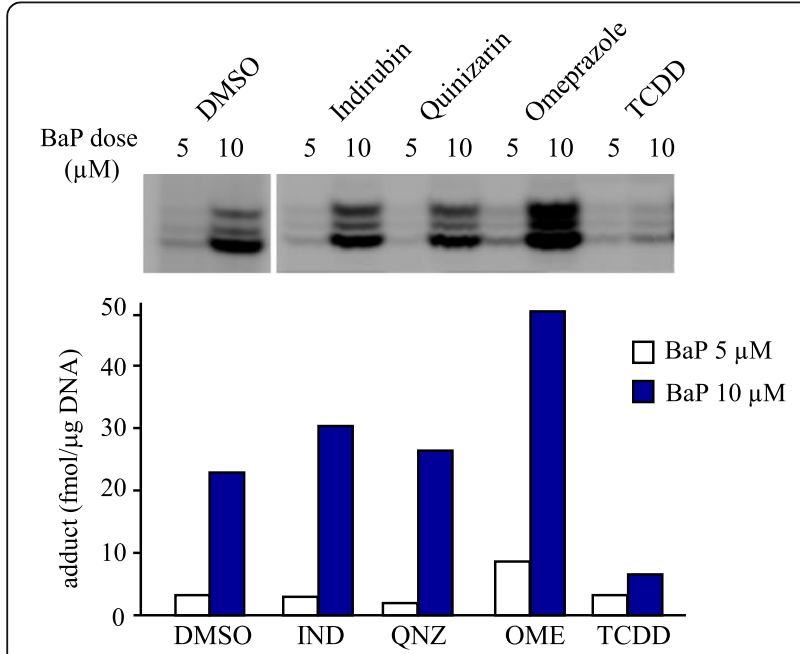

Fig. 1 Alteration of BaP-DNA adduct formation by CYP subtypes and AhR activators. Effect of AhR activator on BaP-DNA adduct formation in HepG2 cells. HepG2 cells were concomitantly treated with $\mathrm{BaP}(5$ or $10 \mu \mathrm{M})$, indirubin (IND, $100 \mathrm{nM})$, quinizarin (QNZ, $10 \mu \mathrm{M})$, omeprazole $(\mathrm{OME}, 100 \mu \mathrm{M})$, or TCDD (10 nM) for $16 \mathrm{~h}$. After incubation, DNA was purified and BaP-DNA adducts were analyzed. This figure is adapted from data reported previously [24] most likely candidate for an enzyme that can transform BPDE to the non-adduct-forming metabolites among the TCDD-inducible drug-metabolizing enzymes.

\section{Alteration of BaP adduct formation by CYP substrates and inhibitors}

AhR modulators showed a wide variety of both protective and aggravative effects on $\mathrm{BaP}$ adduct formation, as shown in Fig. 1. Indirubin, one of the endogenous AhR ligands [40], showed a slight preventive effect. However, the phyto-anthraquinone alizarin [41], which is also regarded as an AhR agonist, did not show any preventive effects. These results can be interpreted as follows. Indirubin and alizarin are not only AhR agonists but also CYP1A1 substrates, which could represent competitive inhibition. From the hypothesis that CYP1A1 activity is crucial for BaP-DNA adduct formation, these chemicals would have dual functions for CYP1A1 and not simply act like TCDD. On the other hand, BaP-DNA adducts were increased by concomitant exposure to $\mathrm{BaP}$ and omeprazole. Omeprazole, a drug for treating gastroesophageal reflux disease, activates AhR without binding as a ligand [42, 43]. Omeprazole-mediated CYP1A1 induction requires more than $12 \mathrm{~h}$ after omeprazole treatment and it is slower than the BaP-mediated CYP1A1 induction [44]. Moreover, omeprazole has inhibitory effects on CYP1A1 as a competitive inhibitor [45]. Thus, the increase of $\mathrm{BaP}$ adducts by omeprazole would be a result that reflected only CYP1A1 inhibition, but not CYP1A1 induction. An AhR antagonist, $\alpha$-naphthoflavone, also increased $\mathrm{BaP}$ adduct formation, and the enhancing effects would be due to CYP1A1 inhibition rather than the effects as an AhR antagonist. In our previous studies, BPDE-induced DNA adducts were reduced by recombinant CYP1A1, and additional $\alpha$-naphthoflavone induced recovery from this reduction [24]. This in vitro assay system was unrelated to AhR-mediated gene transcriptional regulation, so the results support the hypothesis that CYP1A1 can metabolically reduce $\mathrm{BPDE}$. The enhancement of $\mathrm{BaP}-$ DNA adducts by CYP1A1 inhibitors including substrates would be the result of inhibition of the metabolic elimination of BPDE.

\section{Expression of CYP isoforms and BaP-DNA adduct formation}

The induction of CYP1A1 by an AhR agonist caused a reduction of BaP-DNA adducts in HepG2 cells. However, this cell line lacks the expression of CYP1B1, which is another AhR-inducible CYP enzyme transforming BaP to BPDE. The importance of CYP1B1 in BaP metabolism has been well studied both in vivo and in vitro, as has that of CYP1A1 [46-48]. Cyp1a1 knockout mice have shown higher levels of BaP-DNA adducts [38]. However, the loss of Cyp1b1 had little impact on tumor 
response to $\mathrm{BaP}[22,48]$. In ex vivo experiments, CYP1B1 polymorphism and BaP-DNA adducts were also shown to be well correlated [49]. Figure 2 shows the results of our in vitro study using several human cell lines, which express different patterns of CYP isoforms (adapted from data reported elsewhere [24]). The

\section{HepG2 (1A1+, 1B1-)}

A

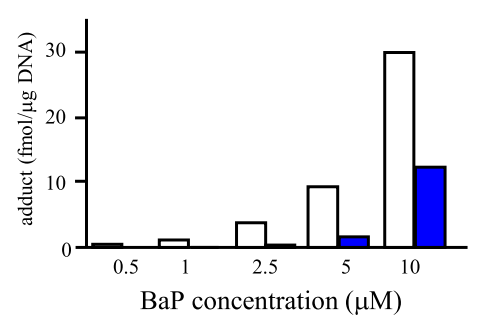

B

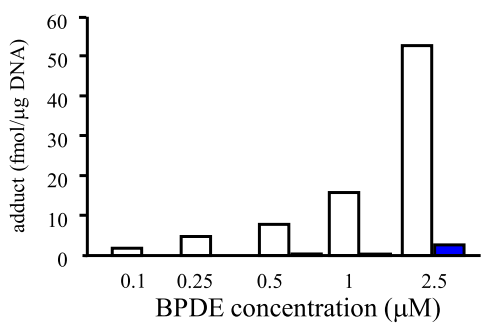

D

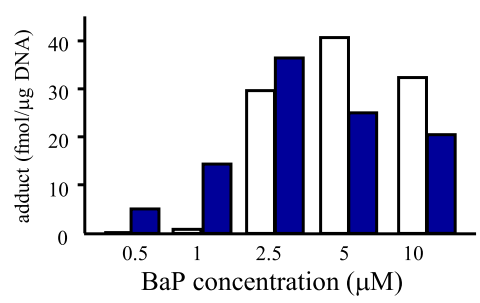

$\mathbf{E}$

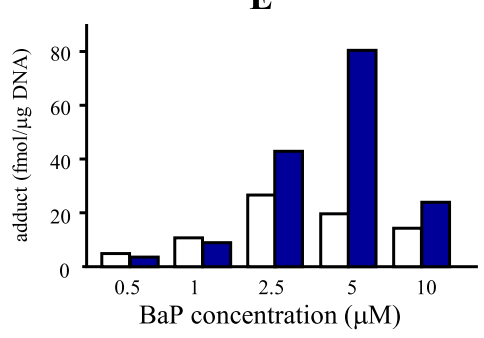

G

CYP1A1 mRNA copy number / ng RNA
F

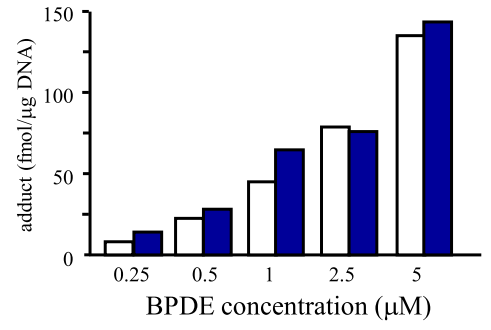

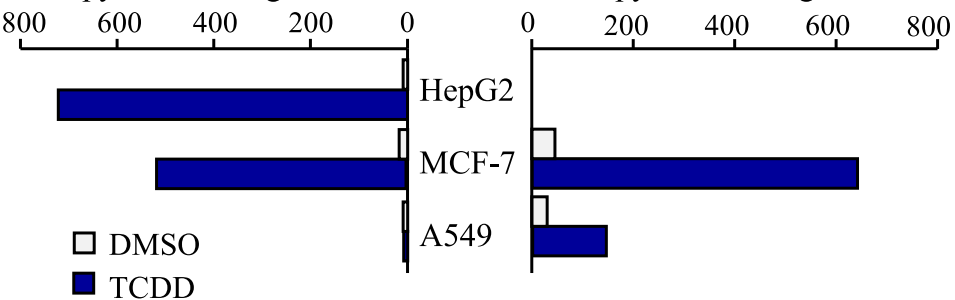

Fig. 2 TCDD-mediated modulation of BaP adducts in various human cell lines. Hepatoma cell line HepG2 (a, b), breast carcinoma cell line MCF7 (c, d), and lung carcinoma cell line $\mathrm{A} 549(\mathbf{e}, \mathbf{f})$ were co-treated with BaP $(0.5-10 \mu \mathrm{M} ; \mathbf{a}, \mathbf{c}, \mathbf{e})$ or BPDE $(0.1-5 \mu \mathrm{M} ; \mathbf{b}, \mathbf{d}, \mathbf{f})$ with or without TCDD. Closed columns represent adducts by $10 \mathrm{nM}$ TCDD treatment and open columns represent adducts by solvent control (DMSO). After $16 \mathrm{~h}$ of incubation, genomic DNA was isolated and DNA adducts were detected by ${ }^{32}$ P-postlabeling and PAGE. G: CYP1A1 and 1B1 mRNA expression in the three cell lines. Each cell line was exposed to $10 \mathrm{nM}$ TCDD or DMSO for $24 \mathrm{~h}$ and total RNA was extracted. For the quantitation of specific transcripts, real-time PCR was performed. These figures are adapted from data reported previously [24] 
modulation of BaP-DNA adducts by TCDD was well correlated to CYP1A1 and CYP1B1 expression. TCDD enhanced BaP-DNA adduct formation in A549 cells that express CYP1B1 but not CYP1A1. Furthermore, TCDD did not influence BPDE-induced DNA adduct formation. In MCF-7 cells expressing both CYP1A1 and CYP1B1, the modulation by TCDD exhibited dual features. TCDD induced adduct formation upon exposure to a low dose of $\mathrm{BaP}$. However, it reduced adduct formation upon high-dose $\mathrm{BaP}$ exposure. In addition, BPDE-induced adduct formation was reduced by TCDD, similar to the results observed with HepG2 cells. These findings can be interpreted as follows: CYP1A1 would be a key enzyme for both the generation and the reduction of $\mathrm{BPDE}$, the major carcinogenic intermediate of $\mathrm{BaP}$, while CYP1B1 has only the former activity. Therefore, it is estimated that various outcomes of changes in adduct formation by concomitant exposure to $\mathrm{BaP}$ and $\mathrm{AhR}$ agonist would arise from the cellular expression of CYP1 isoforms. Similar results were obtained in a study by Genies et al. comparing BaP toxicity in HepG2 and A549 cells; they emphasized the large differences in the responses of cells originating from different organs [50].

\section{Discussion}

Numerous studies have reported on the effects of concomitant exposure or pretreatment of AhR ligands on BaP toxicity. As shown in Table 1, diverse effects, namely, both enhancement and reduction of BaP-DNA adduct formation, were identified. We assert that one of the causes of the earlier confusion is the dual functions of the CYP1A1 enzyme against BaP metabolism. Studies focusing on CYP1A1 regarding BaP toxicity have mainly involved its carcinogenicity via BPDE production over a long period. However, a recent study revealed that CYP1A1 has detoxifying activity on BaP [22]. Our experimental results also constitute evidence that CYP1A1 mediates the elimination of BPDE, and it was estimated

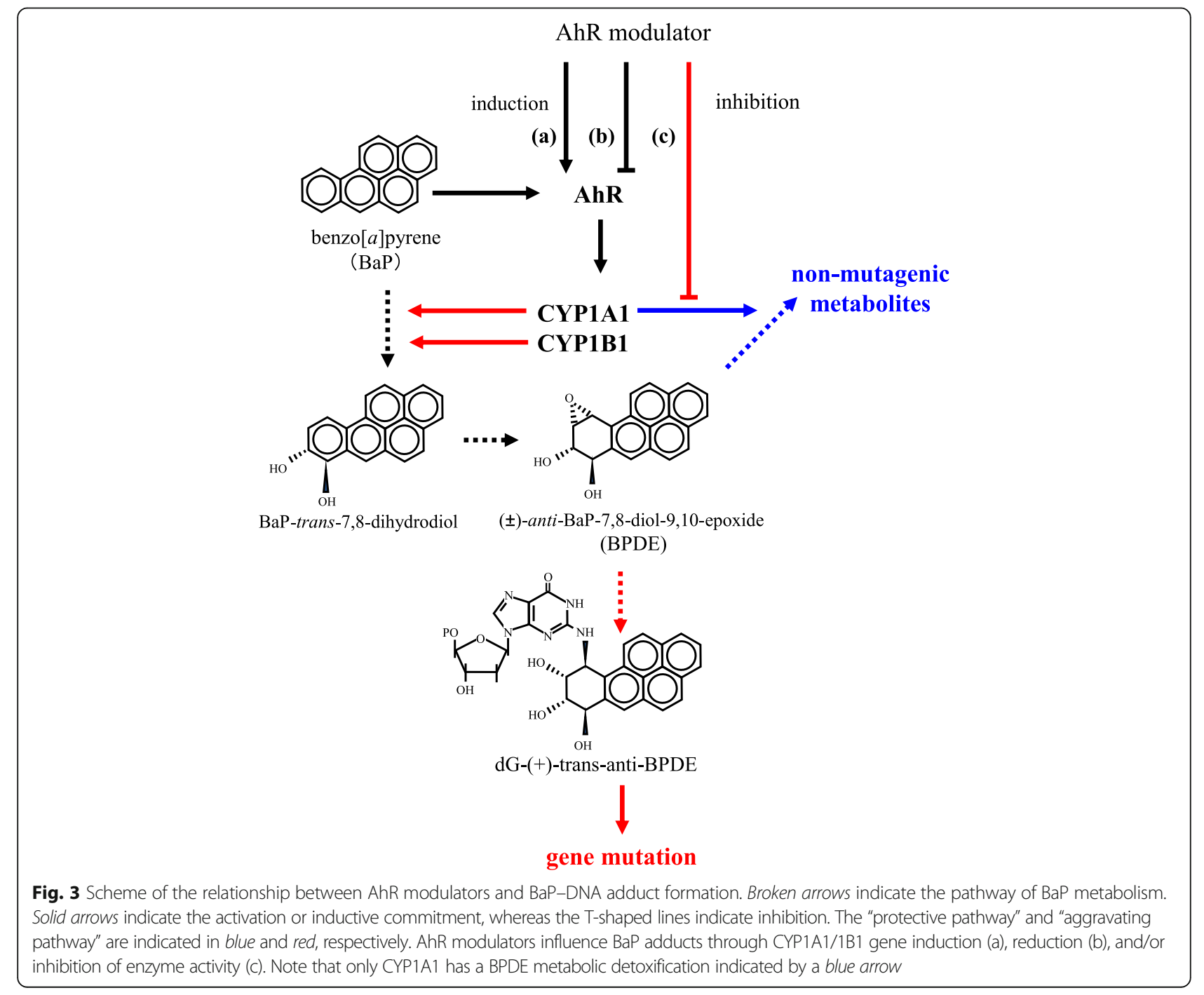


that the AhR agonist can enhance the generation and elimination of BPDE via the induction of CYP1A1. Furthermore, the modulation of $\mathrm{BaP}$ adduct formation by AhR ligand would not be simple because the compound itself occasionally affects CYP enzymes as well as ligands. For example, the widely used AhR antagonist $\alpha$-naphthoflavone is an inhibitor of CYP1A1 at the same time, so it can inhibit not only CYP1A1 gene transcription but also enzyme activity. In addition, omeprazole is a CYP1A1 inhibitor as well as an AhR activator and enhanced $\mathrm{BaP}$ adduct formation. The enhancement by omeprazole would result from CYP1A1 inhibition rather than CYP1A1 induction via AhR. Among AhR-regulated drug-metabolizing enzymes besides CYP1A1, CYP1B1 had a substantial influence on $\mathrm{BaP}$ adduct formation. This enzyme seems to take part in only BPDE production in the process of $\mathrm{BaP}$-induced adduct formation. The difference between CYP1A1 and CYP1B1 in BPDE metabolism impacted not only the sensitivity to BaP, but also the TCDD-mediated modulation of $\mathrm{BaP}$ adduct formation. The scheme in Fig. 3 indicates the relationship between AhR modulators and BaP-DNA adducts. Broken arrows indicate the pathway of $\mathrm{BaP}$ metabolism. Solid arrows indicate the activation or inductive commitment, whereas the T-shaped lines indicate inhibition. The "protective pathway" and "aggravating pathway" are indicated in blue and red, respectively. AhR modulators influence $\mathrm{BaP}$ adducts through CYP1A1/1B1 gene induction (a), reduction (b), and/or inhibition of enzyme activity (c). A recent report showed that impact of individual cytochrome P450 enzymes including CYP1A1 and $1 \mathrm{~B} 1$ in $\mathrm{BaP}$ metabolism [51]. The report showed that CYP1A1 and 1B1 also generate products of detoxification such as 3-hydroxy-BaP. The role of CYP1B1 in the detoxification of $\mathrm{BaP}$ would be limited to the production of these non-reactive metabolites.

CYP1A1 and 1B1 exhibit various tissue distributions. For example, CYP1B1 is abundant in kidney and bone marrow, but these organs scarcely express CYP1A1. Thus, alteration by $\mathrm{AhR}$ agonist to the BaP-adduct formation might depend on the expression profile of CYP1A1 and CYP1B1 in the target tissue. Uno et al. reported tissue-specific differences of BaP toxicity in CYP1A1- and/or CYP1B1-deficient mice [52]. They also reported the importance of $\mathrm{BaP}$ detoxification by CYP1A1 [22]. In addition, Shi et al. reported the differences in the role of CYP1A1 in BaP detoxification between the small intestine and liver by generating tissue-specific knockout mouse models [53]. The insights obtained from in vitro studies can consistently explain the results of these in vivo studies.

At present, we cannot definitively conclude that AhR ligands enhance BaP toxicity in the human body. However, we can predict their effects in organ exhibiting biased expression of CYP1 enzymes, for example, predominant expression of CYP1B1 in lung, and scarce expression of CYP1B1 in liver $[54,55]$. This could explain some of the organ differences in the incidence of cancer caused by smoking and may contribute to developing chemoprevention using AhR ligands or CYP inhibitors.

\section{Conclusion}

The action of the AhR modulators on $\mathrm{BaP}$ adduct formation is the composite result of the several effects including induction, reduction and inhibition of the CYP1 enzymes. CYP1A1 is involved in both the generation and the degradation of BPDE, while CYP1B1 only has activity in generating BPDE. The effects of AhR modulators on BaP-DNA adduct formation depend on the CYP1A1/1B1 expression profile of cells.

\section{Abbreviations}

AhR: Aryl hydrocarbon receptor; ARNT: AhR nuclear translocator; BaP: Benzo[a]pyrene; BPDE: ( \pm )-anti-benzo[a]pyrene-7,8-diol-9,10-epoxide; CYP: Cytochrome P450; GST: Glutathione transferase; TCDD:

2,3,7,8-tetrachlorodibenzo-p-dioxin; UGT: UDP-glucuronosyltransferase

\section{Acknowledgements}

The authors would like to thank Yukari Totsuka, National Cancer Center Research Institute, and Togo Ikuta, Saitama Cancer Center, for giving the opportunity to prepare for this review.

\section{Funding}

This research was supported by Grants-in-Aid for Scientific Research (S) No. 18101002 and (B) No. 24310047 (TY), No. 18101003 (MK), and (C) No. 15 K06849 (KS) from the Japan Society for the Promotion of Science.

Availability of data and materials

This is not applicable to this review. The authors did not generate the data but relied on published studies.

\section{Authors' contributions}

KS and TY participated in research design and wrote or contributed to the writing of the review. TY and MK contributed to establishing the experimental methods and KS designed and carried out the experiments. All authors read and approved the final manuscript.

\section{Competing interests}

The authors declare that they have no competing interests.

Consent for publication

Not applicable.

\section{Ethics approval and consent to participate}

This research does not involve human subjects, human material, human data or animal experimental data.

\section{Author details}

'Department of Applied Biosciences, Faculty of Life Sciences, Toyo University, Itakura, Gunma 374-0193, Japan. ${ }^{2}$ Department of Biological Science, Graduate School of Science, Osaka Prefecture University, Sakai, Osaka, Japan.

Received: 27 December 2016 Accepted: 15 February 2017

Published online: 10 April 2017

References

1. Gelboin HV. Benzo[a]pyrene metabolism activation and carcinogenesis: role and regulation of mixed-function oxidases and related enzymes. Physiol Rev. 1980;60:1107-66. 
2. Hilker DM. Carcinogens occurring naturally in food. Nutr Cancer 1981;2:217-23

3. Hecht SS. Cigarette smoking and lung cancer: chemical mechanisms and approaches to prevention. Lancet Oncol. 2002;3:461-9.

4. Sims P, Grover PL, Swaisland A, Pal K, Hewer A. Metabolic activation of benzo(a)pyrene proceeds by a diol-epoxide. Nature. 1974;252:326-8.

5. Thakker DR, Yagi H, Lu AY, Levin W, Conney AH. Metabolism of benzo[a]pyrene: conversion of (+/-)-trans-7,8-dihydroxy-7,8dihydrobenzo[a]pyrene to highly mutagenic 7,8-diol-9,10-epoxides. Proc Natl Acad Sci U S A. 1976;73:3381-5

6. Kapitulnik J, Wislocki PG, Levin W, Yagi H, Jerina DM, Conney AH. Tumorigenicity studies with diol-epoxides of benzo(a)pyrene which indicate that (+/-)-trans-7beta,8alpha-dihydroxy-9alpha,10alpha-epoxy7,8,9,10-tetrahydrobenzo(a)pyrene is an ultimate carcinogen in newborn mice. Cancer Res. 1978:38:354-8.

7. Schrenk D. Impact of dioxin-type induction of drug-metabolizing enzymes on the metabolism of endo- and xenobiotics. Biochem Pharmacol. 1998;55:1155-62

8. Fujii-Kuriyama Y, Mimura J. Molecular mechanisms of AhR functions in the regulation of cytochrome P450 genes. Biochem Biophys Res Commun. 2005;338:311-7.

9. Ramadoss P, Marcus C, Perdew GH. Role of the aryl hydrocarbon receptor in drug metabolism. Expert Opin Drug Metab Toxicol. 2005;1:9-21.

10. Hoffman EC, Reyes H, Chu FF, Sander F, Conley LH, Brooks BA, et al. Cloning of a factor required for activity of the Ah (dioxin) receptor. Science. 1991;252:954-8.

11. Savas U, Bhattacharyya KK, Christou M, Alexander DL, Jefcoate CR. Mouse cytochrome P-450EF representative of a new 1 B subfamily of cytochrome P-450 s. Cloning sequence determination and tissue expression. J Biol Chem. 1994;269:14905-11.

12. Okey AB, Dubé AW, Vella LM. Binding of benzo(a)pyrene and dibenz(a, h)anthracene to the Ah receptor in mouse and rat hepatic cytosols. Cancer Res. 1984;44:1426-32.

13. Denison MS, Nagy SR. Activation of the aryl hydrocarbon receptor by structurally diverse exogenous and endogenous chemicals. Annu Rev Pharmacol Toxicol. 2003;43:309-34

14. Kang ZC, Tsai SJ, Lee H. Quercetin inhibits benzo[a]pyrene-induced DNA adducts in human Hep G2 cells by altering cytochrome P-450 1A1 gene expression. Nutr Cancer. 1999;35:175-9.

15. Hodek P, Koblihová J, Kizek R, Frei E, Arlt VM, Stiborová M. The relationship between DNA adduct formation by benzo[a]pyrene and expression of its activation enzyme cytochrome P450 1A1 in rat. Environ Toxicol Pharmacol. 2013;36:989-96.

16. Mohebati A, Guttenplan JB, Kochhar A, Zhao ZL, Kosinska W, Subbaramaiah K, Dannenberg AJ, et al. Carnosol a constituent of Zyflamend inhibits aryl hydrocarbon receptor-mediated activation of CYP1A and CYP1B1 transcription and mutagenesis. Cancer Prev Res (Phila). 2012;4:593-602.

17. Revel A, Raanani H, Younglai E, Xu J, Rogers I, Han R, et al. Resveratrol a natural aryl hydrocarbon receptor antagonist protects lung from DNA damage and apoptosis caused by benzo[a]pyrene. J Appl Toxicol. 2003;23:255-61.

18. Shimizu Y, Nakatsuru Y, Ichinose M, Takahashi Y, Kume H, Mimura J, et al. Benzo[a]pyrene carcinogenicity is lost in mice lacking the aryl hydrocarbon receptor. Proc Natl Acad Sci U S A. 2000;97:779-82.

19. Wu Q, Suzuki JS, Zaha H, Lin TM, Peterson RE, Tohyama C, Ohsako S. Differences in gene expression and benzo[a]pyrene-induced DNA adduct formation in the liver of three strains of female mice with identical AhRb2 genotype treated with 2,3,7,8-tetrachlorodibenzo-pdioxin and/or benzo[a]pyrene. J Appl Toxicol. 2008;28:724-33.

20. de Waard PW, de Kok TM, Maas LM, Peijnenburg AA, Hoogenboom RL, Aarts JM, et al. Influence of TCDD and natural Ah receptor agonists on benzo[a]pyrene-DNA adduct formation in the Caco-2 human colon cell line. Mutagenesis. 2008;23:67-73.

21. Gelhaus SL, Harvey RG, Penning TM, Blair IA. Regulation of benzo[a]pyrenemediated DNA- and glutathione-adduct formation by 2,3,7,8tetrachlorodibenzo-p-dioxin in human lung cells. Chem Res Toxicol. 2011;24:89-98.

22. Sagredo C, Øvrebø S, Haugen A, Fujii-Kuriyama Y, Baera R, Botnen IV, et al. Quantitative analysis of benzo[a]pyrene biotransformation and adduct formation in Ahr knockout mice. Toxicol Lett. 2006;167:173-82.
23. Harrigan JA, Vezina $C M$, McGarrigle BP, Ersing N, Box HC, Maccubbin AE, et al. DNA adduct formation in precision-cut rat liver and lung slices exposed to benzo[a]pyrene. Toxicol Sci. 2004;77:307-14.

24. Shiizaki K, Kawanishi M, Takashi Y. Dioxin suppresses benzo[a]pyreneinduced mutations and DNA adduct formation hrough cytochrome P450 1A1 induction and ( \pm )-anti-benzo[a]pyrene-7,8-diol-9,10-epoxide inactivation in human hepatoma cells. Mutat Res. 2013;750:77-85.

25. Chang KW, Lee H, Wang HJ, Chen SY, Lin P. Differential response to benzo[A]pyrene in human lung adenocarcinoma cell lines: the absence of aryl hydrocarbon receptor activation. Life Sci. 1999:65:1339-49.

26. Takemura H, Nagayoshi H, Matsuda T, Sakakibara H, Morita M, Matsui A, et al. Inhibitory effects of chrysoeriol on DNA adduct formation with benzo[a]pyrene in MCF-7 breast cancer cells. Toxicology. 2010;274:42-8.

27. Wen X, Walle UK, Walle T. 5,7-Dimethoxyflavone downregulates CYP1A1 expression and benzo[a]pyrene-induced DNA binding in Hep G2 cells. Carcinogenesis. 2005;26:803-9.

28. Sehgal A, Kumar M, Jain M, Dhawan DK. Modulatory effects of curcumin in conjunction with piperine on benzo(a)pyrene-mediated DNA adducts and biotransformation enzymes. Nutr Cancer. 2013;65:885-90.

29. Kleiner HE, Reed MJ, DiGiovanni J. Naturally occurring coumarins inhibit human cytochromes P450 and block benzo[a]pyrene and 7,12dimethylbenz[a]anthracene DNA adduct formation in MCF-7 cells. Chem Res Toxicol. 2003;16:415-22.

30. Wincent E, Bengtsson J, Mohammadi Bardbori A, Alsberg T, Luecke S, Rannug U, et al. Inhibition of cytochrome P4501-dependent clearance of the endogenous agonist FICZ as a mechanism for activation of the aryl hydrocarbon receptor. Proc Natl Acad Sci U S A. 2012;10912:4479-84.

31. Yun $\mathrm{CH}$, Shimada T, Guengerich FP. Roles of human liver cytochrome P4502C and 3A enzymes in the 3-hydroxylation of benzo(a)pyrene. Cancer Res. 1992;52:1868-74.

32. Nebert DW, Dalton TP, Okey AB, Gonzalez FJ. Role of aryl hydrocarbon receptor-mediated induction of the CYP1 enzymes in environmental toxicity and cancer. J Biol Chem. 2004;279:23847-50.

33. Sundberg K, Widersten M, Seidel A, Mannervik B, Jernstrom B. Glutathione conjugation of bay- and fjord-region diol epoxides of polycyclic aromatic hydrocarbons by glutathione transferases $\mathrm{M} 1-1$ and $\mathrm{p} 1-1$. Chem Res Toxicol. 1997;10:1221-7.

34. Fang JL, Beland FA, Doerge DR, Wiener D, Guillemette C, Marques MM, et al. Characterization of benzo(a)pyrene-trans-7,8-dihydrodiol glucuronidation by human tissue microsomes and overexpressed UDP-glucuronosyltransferase enzymes. Cancer Res. 2002;62:1978-86.

35. Wrighton SA, Stevens JC, Becker GW, VandenBranden M. Isolation and characterization of human liver cytochrome P450 2C19: correlation between 2C19 and S-mephenytoin 4'-hydroxylation. Arch Biochem Biophys. 1993;306:240-5.

36. Sutter TR, Tang YM, Hayes CL, Wo YY, Jabs EW, Li X, et al. Complete CDNA sequence of a human dioxin-inducible mRNA identifies a new gene subfamily of cytochrome P450 that maps to chromosome 2. J Biol Chem. 1994;269:13092-9.

37. Schulz TG, Thiel R, Neubert D, Brassil PJ, Schulz-Utermoehl T, Boobis AR, et al. Assessment of P450 induction in the marmoset monkey using targeted anti-peptide antibodies. Biochim Biophys Acta. 2001;1546:143-55.

38. Shimada T, Gillam EM, Oda Y, Tsumura F, Sutter TR, Guengerich FP, et al. Metabolism of benzo[a]pyrene to trans-7,8-dihydroxy-7 8dihydrobenzo[a]pyrene by recombinant human cytochrome P450 1B1 and purified liver epoxide hydrolase. Chem Res Toxicol. 1999;12:623-9.

39. Zhu QS, Qian B, Levy D. Regulation of human microsomal epoxide hydrolase gene (EPHX1) expression by the transcription factor GATA-4. Biochim Biophys Acta. 2004;1676:251-60.

40. Adachi J, Mori Y, Matsui S, Takigami H, Fujino J, Kitagawa H, et al. Indirubin and indigo are potent aryl hydrocarbon receptor ligands present in human urine. J Biol Chem. 2001;276:31475-8.

41. Amakura Y, Tsutsumi T, Sasaki K, Yoshida T, Maitani T. Screening of the inhibitory effect of vegetable constituents on the aryl hydrocarbon receptor-mediated activity induced by 2,3,7,8-tetrachlorodibenzo-p-dioxin. Biol Pharm Bull. 2003;26:1754-60.

42. Lind T, Cederberg C, Ekenved G, Haglund U, Olbe L. Effect of omeprazole - a gastric proton pump inhibitor-on pentagastrin stimulated acid secretion in man. Gut. 1983;24:270-6.

43. Daujat M, Peryt B, Lesca P, Fourtanier G, Domergue J, Maurel P. Omeprazole an inducer of human CYP1A1 and $1 \mathrm{~A} 2$ is not a ligand for the Ah receptor. Biochem Biophys Res Commun. 1992;188:820-5. 
44. Backlund $M$, Ingelman-Sundberg M. Regulation of aryl hydrocarbon receptor signal transduction by protein tyrosine kinases. Cell Signal. 2005;17:39-48.

45. Shiizaki K, Ohsako S, Kawanishi M, Yagi T. Omeprazole alleviates benzo[a]pyrene cytotoxicity by inhibition of CYP1A1 activity in human and mouse hepatoma cells. Basic Clin Pharmacol Toxicol. 2008;103:468-75.

46. Uppstad H, Øvrebø S, Haugen A, Mollerup S. Importance of CYP1A1 and CYP1B1 in bioactivation of benzo[a]pyrene in human lung cell lines. Toxicol Lett. 2010;192:221-8.

47. Siddens LK, Bunde KL, Harper Jr TA, McQuistan TJ, Löhr CV, Bramer LM, et al. Cytochrome P450 1b1 in polycyclic aromatic hydrocarbon (PAH)-induced skin carcinogenesis: Tumorigenicity of individual PAHs and coal-tar extract DNA adduction and expression of select genes in the Cyp1b1 knockout mouse. Toxicol Appl Pharmacol. 2015;287:149-60.

48. Moorthy B, Miller KP, Jiang W, Williams ES, Kondraganti SR, Ramos KS Role of cytochrome P4501B1 in benzo[a]pyrene bioactivation to DNAbinding metabolites in mouse vascular smooth muscle cells: evidence from ${ }^{32}$ P-postlabeling for formation of 3-hydroxybenzo[a]pyrene and benzo[a]pyrene-3,6-quinone as major proximate genotoxic intermediates. J Pharmacol Exp Ther. 2003;305:394-401.

49. Schults MA, Chiu RK, Nagle PW, Wilms LC, Kleinjans JC, van Schooten FJ, et al. Genetic polymorphisms in catalase and CYP1B1 determine DNA adduct formation by benzo(a)pyrene ex vivo. Mutagenesis. 2013;28:181-5.

50. Genies C, Maître A, Lefèbvre E, Jullien A, Chopard-Lallier M, Douki T. The extreme variety of genotoxic response to benzo[a]pyrene in three different human cell lines from three different organs. PLoS One. 2013;8, e78356.

51. Šulc M, Indra R, Moserová M, Schmeiser HH, Frei E, Arlt VM, Stiborová M. The impact of individual cytochrome P450 enzymes on oxidative metabolism of benzo[a]pyrene in human livers. Environ Mol Mutagen. 2016;57:229-35

52. Nebert DW, Shi Z, Gálvez-Peralta M, Uno S, Dragin N. Oral benzo[a]pyrene: understanding pharmacokinetics detoxication and consequences-Cyp1 knockout mouse lines as a paradigm. Mol Pharmacol. 2013;84:304-13.

53. Shi Z, Dragin N, Gálvez-Peralta M, Jorge-Nebert LF, Miller ML, Wang B, et al. Organ-specific roles of CYP1A1 during detoxication of dietary benzo[a]pyrene. Mol Pharmacol. 2010;78:46-57.

54. Spivack SD, Hurteau GJ, Reilly AA, Aldous KM, Ding X, Kaminsky LS. CYP1B1 expression in human lung. Drug Metab Dispos. 2001;29:916-22.

55. Vanhees K, van Schooten FJ, Moonen EJ, Maas LM, van Waalwijk van Doorn-Khosrovani SB, Godschalk RW. Maternal intake of quercetin during gestation alters ex vivo benzo[a]pyrene metabolism and DNA adduct formation in adult offspring. Mutagenesis. 2012;27:445-51.

\section{Submit your next manuscript to BioMed Central and we will help you at every step:}

- We accept pre-submission inquiries

- Our selector tool helps you to find the most relevant journal

- We provide round the clock customer support

- Convenient online submission

- Thorough peer review

- Inclusion in PubMed and all major indexing services

- Maximum visibility for your research

Submit your manuscript at www.biomedcentral.com/submit

) Biomed Central 